\title{
POLARISASI MANAJEMEN STRATEGIK PENDIDIKAN DALAM IMPLEMENTASI FULL DAY SCHOOL
}

\author{
Agus Fahmi \\ Administrasi Pendidikan, FIP IKIP Mataram \\ Email:fahmi_ap@ikipmataram.ac.id
}

\begin{abstract}
Educational administrators (principals, head of education) as of today's modern executive should be able to observe and respond to all the challenges posed by the external environment both near and far. The decision makers, including principals and education managers more often forced to beat the demands of activities educational institutions in order to serve a variety of purposes such as routine affairs, department, work must always be under the instructions or guidelines set by the bureaucracy without considering the needs of system implementation Full Day School with Extra hours are longer in school, ie at least eight (8) hours per day into something new so that the decision process is often not optimal in generating strategic decisions. As a result, actual problems faced by educational institutions can not be resolved to the fullest. The method used in this study is a qualitative research design phenomenon that already exists in a reasonable and natural, making it possible to carry out in-depth interviews with the study subjects. Therefore, it is very important to do a study that will reveal the need for better strategic management in order to generate the proper decision-making process for the development and advancement of educational institutions. The results showed that polarization in the implementation of FDS is very sharp, it is characterized by readiness Resources are not fully adequate in terms of Cost Source, Infrastructures, facilities, as well as Human Resources.
\end{abstract}

\section{Keywords: Strtegic Management, Fullday School}

\begin{abstract}
Abstrak: Pengelola pendidikan (kepala sekolah, kepala dinas pendidikan) sebagai eksekutif modern saat ini harus mampu mengamati dan merespons segenap tantangan yang dimunculkan oleh lingkungan eksternal baik yang dekat maupun yang jauh. Para pengambil keputusan, termasuk kepala sekolah maupun pengelola pendidikan lainnya seringkali terpaksa mengalahkan tuntutan kegiatan lembaga pendidikan demi melayani bermacam kepentingan seperti urusan rutin, dinas, bekerja harus selalu di bawah petunjuk atau pedoman kerja yang ditetapkan oleh birokrasi tanpa mempertimbangkan kebutuhan Penerapan sistem Full Day School dengan penambahan jam yang lebih panjang di sekolah, yaitu minimal 8 (delapan) jam perhari menjadi hal baru sehingga proses pengambilan keputusan seringkali tidak maksimal dalam menghasilkan keputusan-keputusan strategis. Akibatnya persoalan aktual lembaga pendidikan yang dihadapi tidak dapat terselesaikan secara maksimal. Metode yang dipakai dalam penelitian ini adalah desain penelitian kualitatif dengan fenomena yang sudah ada secara wajar dan natural, sehingga memungkinkan untuk melakukan wawancara mendalam dengan subjek penelitian. Oleh karena itu, sangat penting dilakukan sebuah penelitian yang akan mengungkap kebutuhan akan manajemen strategik yang baik guna menghasilkan proses pengambilan keputusan yang tepat untuk perkembangan dan kemajuan lembaga pendidikan. Hasil penelitian ini menunjukkan bahwa Polarisasi dalam pelaksanaan FDS sangatlah tajam, hal tersebut ditandai dengan kesiapan Sumber Daya yang belum sepenuhnya memadai dari segi Sumber Biaya, Sarana dan Prasarana, fasilitas, maupun Sumber Daya Manusianya.
\end{abstract}

Kata kunci: Manajemen Strategik, Full Day School

\section{LATAR BELAKANG}

Pendidikan Nasional Indonesia saat ini terus mengalami perubahan Sistem seiring perkembangan dan kemajuan dalam berbagai sudut kehidupan. Pergeseran nilai dan kebiasaan masyarakat pada perspektif sosial kebudayaan tanpa disadari terpengaruh oleh kemajuan ilmu pengetahuan dan teknologi yang begitu pesat. Manajemen pendidikan yang diterapkan di lingkungan internal sistem persekolahan hanyalah sebagian dari tanggung jawab kepala sekolah sebagai manajer pendidikan. Para pengelola pendidikan (kepala sekolah, kepala dinas pendidikan) sebagai eksekutif modern saat ini harus mampu mengamati dan merespons segenap tantangan yang dimunculkan oleh lingkungan eksternal baik yang dekat maupun yang jauh. Lingkungan eksternal dekat adalah lingkungan yang mempunyai pengaruh langsung pada operasional lembaga pendidikan, seperti berbagai potensi dan keadaan dalam bidang pendidikan yang menjadi konsentrasi usaha sekolah itu sendiri, situasi persaingan, situasi 
pelanggan pendidikan, dan pengguna lulusan. Kesemuanya berpengaruh pada penentuan strategi yang diperkirakan mendukung sekolah mencapai tujuannya. Lingkungan eksternal yang jauh adalah berbagai kekuatan dan kondisi yang muncul di luar lingkungan eksternal yang dekat meliputi keadaan sosial ekonomi, politik, keamanan nasional, perkembangan teknologi, dan tantangan global. Secara tidak langsung berpengaruh terhadap penyelenggaraan sistem pendidikan di suatu sekolah.

Para pengambil keputusan, termasuk kepala sekolah maupun pengelola pendidikan lainnya seringkali terpaksa mengalahkan tuntutan kegiatan lembaga pendidikan demi melayani bermacam kepentingan seperti urusan rutin, dinas, bekerja harus selalu di bawah petunjuk atau pedoman kerja yang ditetapkan oleh birokrasi tanpa mempertimbangkan kebutuhan Penerapan sistem Full Day School dengan penambahan jam yang lebih panjang di sekolah, yaitu minimal 8 (delapan) jam perhari menjadi hal baru sehingga proses pengambilan keputusan seringkali tidak maksimal dalam menghasilkan keputusan-keputusan strategis. Akibatnya persoalan aktual lembaga pendidikan yang dihadapi tidak dapat terselesaikan secara maksimal.

KAJIAN PUSTAKA

Definisi Umum Manajemen Strategik

Manajemen strategik adalah seni dan pengetahuan dalam merumuskan, mengimplementasikan, serta mengevaluasi keputusan-keputusan lintas fungsional yang memungkinkan sebuah organisasi untuk mencapai tujuan (David, 2011:6). Manajemen strategis berfokus pada proses penetapan tujuan organisasi, pengembangan kebijakan dan perencanaan untuk mencapai sasaran, serta mengalokasikan sumber daya untuk menerapkan kebijakan dan merencanakan pencapaian tujuan organisasi. Manajemen strategis mengkombinasikan aktivitas-aktivitas dari berbagai bagian fungsional suatu bisnis untuk mencapai tujuan organisasi. Beberapa ahli berpendapat bahwa:

a. Thomas Wheelen dkk (2010:105), Manajemen strategi adalah serangkaian dari pada keputusan manajerial dan kegiatan-kegiatan yang menentukan keberhasilan perusahaan dalam jangka panjang. Kegiatan tersebut terdiri dari perumusan/perencanaan strategi, pelaksanaan/implementasi dan evaluasi.

b. Bambang Haryadi (2003:3), strategi manajemen adalah suatu proses yang dirancang secara sistematis oleh manajemen untuk merumuskan strategi, menjalankan strategi dan mengevaluasi strategi dalam rangka menyediakan nilainilai yang terbaik bagi seluruh pelanggan untuk mewujudkan visi organisasi.

c. Mulyadi (2001:40), Manajemen strategi adalah suatu proses yang digunakan oleh manajer dan karyawan untuk merumuskan dan mengimplementasikan strategi dalam penyediaan costumer value terbaik untuk mewujudkan visi organisasi.

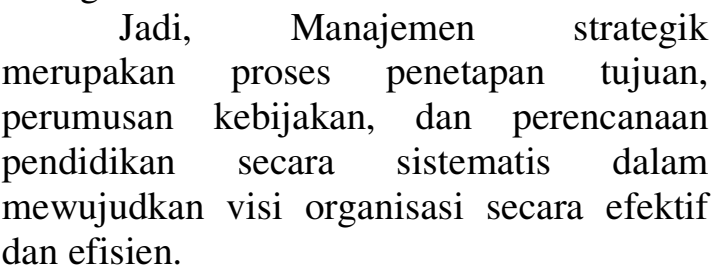

\section{Tujuan Manajemen Strategi}

Suwandiyanto (2010:02), terdapat empat tujuan manajemen strategi, yaitu:

a. Memberikan arah pencapaian tujuan organisasi/perusahaan. Dalam hal ini, manajer strategi harus mampu menunjukkan kepada semua pihak kemana arah tujuan organisasi/perusahaan. Karena, arah yang jelas akan dapat dijadikan landasan untuk pengendalian dan mengevaluasi keberhasilan.

b. Membantu memikirkan kepentingan berbagai pihak. Organisasi/perusahaan harus mempertemukan kebutuhan berbagai pihak, pemasok, karyawan, pemegang saham, pihak perbankan, dan masyarakat luas lainnya yang memegang 
peranan terhadap sukses atau gagalnya perusahaan.

c. Mengantisipasi setiap perubahan kembali secara merata. Manajemen strategi memungkinkan eksekutif puncak untuk mengantisipasi perubahan dan menyiapkan pedoman dan pengendalian, sehingga dapat memperluas kerangka waktu/berpikir mereka secara perspektif dan memahami kontribusi yang baik untuk hari ini dan hari esok.

d. Berhubungan dengan efisiensi dan efektivitas. Tanggung jawab seorang manajer bukan hanya mengkonsentrasikan terhadap kemampuan atas kepentingan efisiensi, akan tetapi hendaknya juga mempunyai perhatian yang serius agar bekerja keras melakukan sesuatu secara lebih baik dan efektif.

\section{Model Manajemen Strategik}

Manajemen strategik berawal dari mengidentifikasi visi organisasi yang sudah ada, misi, tujuan, dan strategi adalah titik awal yang logis untuk manajemen strategis karena situasi sekarang perusahaan dan kondisi dapat menghalangi strategi tertentu dan bahkan mungkin mendikte tindakan tertentu. Setiap organisasi memiliki visi, misi, tujuan, dan strategi,bahkan jika unsurunsur ini tidak sadar dirancang, ditulis, atau dikomunikasikan.

Manajemen strategik memiliki tahapan atau proses yang disusun dan terstruktur dalam bentuk model seperti gambar di bawah ini:

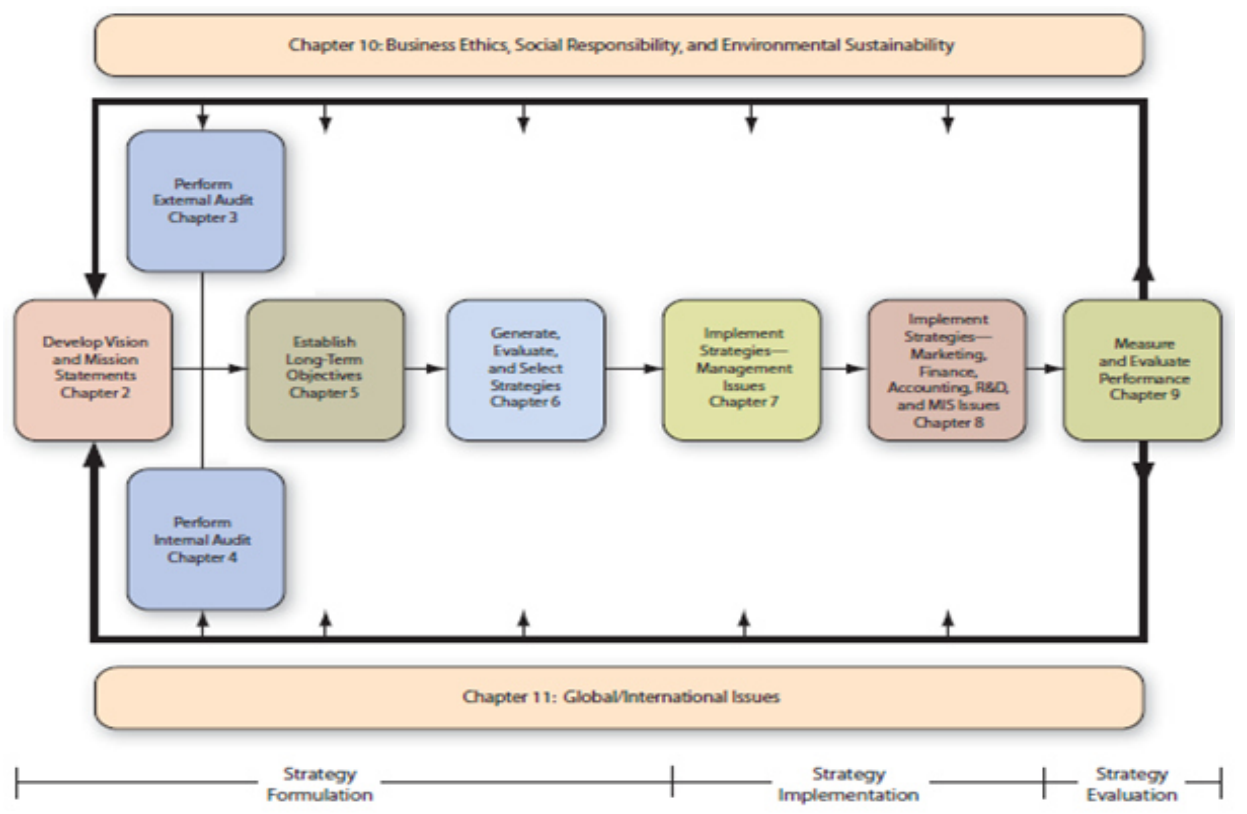

Gambar 2.1 Model Proses Manajemen Strategik (David, 2011:15)

\section{Full Day School}

Full day school selain bertujuan mengembangkan manajemen mutu pendidikan yang paling utama adalah full day school bertujuan sebagai salah satu upaya pembinaan akidah dan akhlak siswa dan menanamkan nilai-nilai positif. Full day school juga memberikan dasar yang kuat dalam belajar pada segala aspek yaitu perkembangan intelektual, fisik, sosial dan emosional. Karena dalam sistem full day school, sekolah memiliki waktu yang lebih panjang dibandingkan dengan sekolah dasar konvensional pada umumnya. Sebagaimana Seli (2009: 62-63) mengatakan bahwa "waktu untuk mendidik siswa dalam sistem full day school lebih banyak sehingga tidak hanya teori, tetapi praktek mendapatkan proporsi waktu yang lebih. Sehingga pendidikan tidak hanya teori mineed tetapi aplikasi ilmu". Oleh karena itu, agar semua terakomodir, maka kurikulum program full 
day school didesain untuk menjangkau masing-masing bagian dari perkembangan siswa.

\section{METODE PENELITIAN}

Penelitian ini berupaya mengungkap

Polarisasi Manajemen Strategik Pendidikan dalam Implementasi Full day School. Metode penelitian yang digunakan pada penelitian ini adalah metode penelitian kualitatif yaitu pendekatan yang temuantemuan penelitiannya tidak diperoleh melalui prosedur statistik atau bentuk perhitungan lainnya, prosedur ini menghasilkan temuan-temuan yang diperoleh dari data-data yang dikumpulkan dengan menggunakan beragam sarana meliputipengamatan dan wawancara, namun bisa juga mencakup dokumen, buku, kasetvideo, dan bahkan data yang telah dihitung untuk tujuan lain, misalnya data sensus.

Dalam penelitian kualitatif langkahlangkah/tahap-tahapan itu secara garis besar dibagi kedalam tiga bagian, yaitu; 1) Tahapan persiapan/pra-lapangan, 2) Tahapan pekerjaan lapangan, dan 3) Tahapan analisis data. Adapun rincian tahapan-tahapan tersebut adalah sebagai beriku:

1) Pra-Lapangan

2) Pengolahan Data

a. Reduksi data

b. Display data

c. Analisis

Menurut Miles dan Huberman (1992) analisis data terdiri dari tiga alur kegiatan yang terjadi secara bersamaan yaitu: reduksi data, penyajian data, menarik kesimpulan/verifikasi. Secara skematis dapat dilihat pada gambar berikut ini:

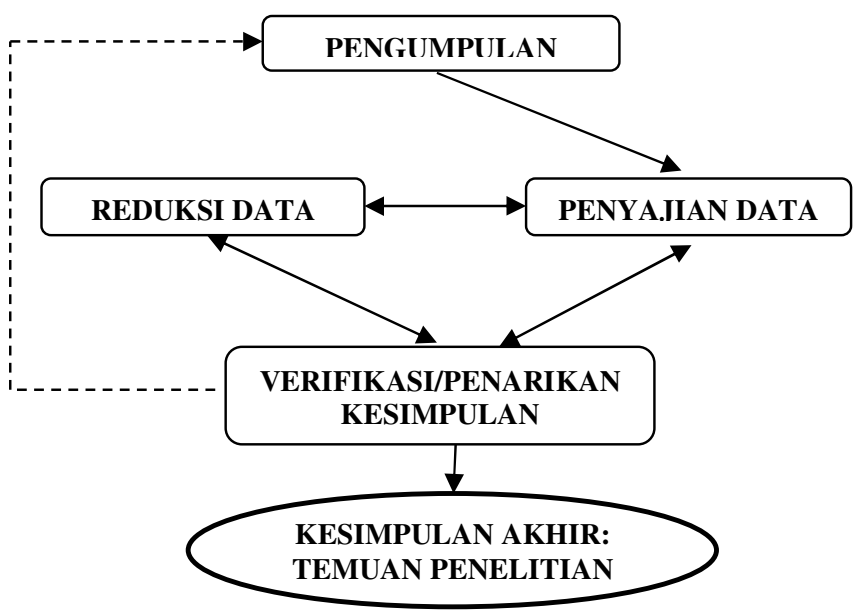

Gambar 2.1 Pola Interaktif Analisis Data Penelitian (Diadopsi dari Miles \& Huberman, 1984:23)

a. Reduksi Data

Reduksi data merupakan suatu bentuk analisis yang menajamkan, menggolongkan, mengarahkan, membuang yang tidak perlu, dan mengorganisasi data sedemikian rupa sehingga diperoleh kesimpulan akhir dan diverifikasi. Reduksi data ini berlangsung secara terus-menerus selama penelitian berlangsung.

\section{b. Penarikan Kesimpulan}

Analisis data yang dikumpulkan selama pengumpulan data sesudah pengumpulan data digunakan untuk menarik suatu kesimpulan, sehingga dapat menggambarkan suatu pola tentang peristiwa-peristiwa yang terjadi. Analisa data yang terus-menerus dilakukan mempunyai implikasi terhadap pengurangan dan penambahan data yang dibutuhkan. Hal ini 
memungkinkan peneliti untuk kembali kelapangan.

\section{c. Pengecekan Keabsahan Data}

Keabsahan data merupakan hal yang sangat penting dalam penelitian kualitatif. Informasi yang telah berhasil dikumpulkan oleh peneliti dan akan dijadikan data dalam penelitian ini perlu diperiksa kredibilytasnya, sehingga data penelitian tersebut dapat dipertanggung jawabkan dan dapat dijadikan sebagai dasar yang kuat dalam menarik kesimpulan. Bogdan \& Biklen (1990), mengatakan bahwa dalam penelitian dengan pendekatan kualitatif, peneliti merupakan instrumen utamanya. Oleh karena peneliti sebagai instrumen utamanya maka uji validitas dan reabilitas instrumen penelitian bukan dengan cara menguji cobakan instrumen, melainkan melalui pemeriksaan kredibilytas dan pengauditan datanya.

\section{HASIL DAN PEMBAHASAN}

\section{Polemik FDS}

Sejak FDS secara resmi diterapkan kerap kali menuai polemik di masyarakat. Polemik tersebut dapat dilihat dari beberapa faktor, yakni di antaranya faktor kelembagaan, orang tua-siswa, sociokultural dan kesejahteraan. Faktor kelembagaan berupa ketidak-siapan beberapa sekolah yang menerapkan FDS. Ketidak-siapan sekolah ini dibuktikan dari beberapa sekolah belum memiliki guru yang kompeten untuk menciptakan suasana belajar yang interaktif dan menarik. Hal ini juga termasuk fasilitas sekolah yang belum memadai sehingga terkesan memaksakan. Kurangnya pengawasan dari pemerintah dalam penerapan FDS mengakibatkan tujuan pendidikan karakter tidak tercapai. Terlebih lagi kerjasama yang harus dilakukan oleh pemerintah dengan berbagai kelembagaan yang terkait seperti Kementerian Agama, Komisi Perlindungan Anak Indonesia (KPAI), Komisi Nasional Hak Asasi Manusia (Komnas HAM), Ombudsman, Komisi Informasi Publik, LSM, Pusat-Pusat Kajian dan berbagai lembaga terkait. Hal ini guna mengkajiulang apa saja yang perlu dipertimbangkan sebelum FDS secara resmi diterapkan di Indonesia. Selain dari itu, dari faktor kelembagaan juga perlu dilihat tataran kewenangan dan kebijakan yang dari segi peraturan perundang-undangan, apakah FDS ini secara legitimasi sudah selesai atau belum.

\section{Konsep FDS dan Kurikulum Konvensional}

Full Day School, merupakan suatu program yang sedang hangat dalam Pendidikan Indonesia. Yang artinya Pemerintah melakukan perubahan dalam Pendidikan Indonesia yang merubah dari segi jam pembelajaran dari belajar hingga delapan jam menjadi seharian penuh atau dapat dikatakan sampai sore. Proses belajar ini dapat mengahabiskan waktu peserta didik dalam hal berbagai kesibukannya di rumah maupun di masyarakat. Dengan kata lain peserta didik tidak dapat melakukan hal-hal yang berkaitan dengan kegiatan di luar sekolah, karena peserta didik sudah bosan akan adanya materi yang diberikan kepada pihak sekolah seharian penuh. Menurut pemerintah diadakannya Full Day School adalah untuk menjawab semua permasalahan yang dialami di dalam dunia Pendidikan Indonesia. Akan tetapi, banyak masyarakat yang menolak akan adanya penerapan Full Day School ini, karena kurangnya istirahat peserta didik di rumah atau berkumpulnya dengan keluarga dan sanak saudara. Dalam hal ini dimaksudkan adalah untuk penguatan karakter peserta didik dan untuk memenuhi kewajiban guru dengan melaksanakan tugasnya dalam hal mendidik peserta didik. Sementara itu dengan berlakunya kurikulum 2013 ini, orang tua peserta didik tidak dapat memahami apa maksud dari kurikulum tersebut. Apalagi ditambah dengan diadakannya Full Day School, orang tua peserta didik nampak tidak akan paham dengan apa yang diinginkan oleh pemerintah saat ini. Sama halnya dengan kurikulum 2013 banyak pro dan kontra dimana-mana 
yang mana kita tahu dalam Kurikulum 2013 ini bukanlah hal yang baru, karena pada kurikulum sebelumnya terdapat yang namanya Kurikulum KTSP (Kurikulum Tingkat Satuan Pendidikan) atau lebih dikenal dengan Kurikulum 2006 yang dikombinasikan dengan CBSA (Cara Belajar Siswa Aktif). Dimana CBSA ini adalah suatu pendekatan dalam proses belajar mengajar yang menitik beratkan pada keaktifan siswa sama halnya dengan Kurikulum 2013 ini, bisa dibilang Student Center.

\section{Hilirisasi Polarisasi FDS}

Gambaran mengenai program full day school adalah: Aspek kelembagaan, kepemimpinan dan manajemen, mengacu kepada konsep yang dikembangkan sekolah program full day school yang mengedepankan kemuliaan akhlaq dan prestasi akademik. Kepemimpinan sekolah dipacu dengan peningkatan kualitas kepribadian, peningkatan kemampuan manajerial dan pengetahuan konsep-konsep pendidikan kontemporer yang didukung dengan kegiatan short-course, orientasi program, dan studi banding, dimana program-program ini dilaksanakan secara simultan dan kontinu. Kualitas sumber daya full day school dipilih dari guru-guru bidang studi yang professional, berkualitas dan mempunyai integritas yang tinggi. Peningkatan kualitas tenaga kependidikan seperti tenaga kependidikan seperti tenaga ahli perpustakaan, laborat dan administrasi juga merupakan fokus garapan dalam peningkatan kualitas sekolah program full day school. Mengenai konsep dalam system full day school adalah sebagai berikut:

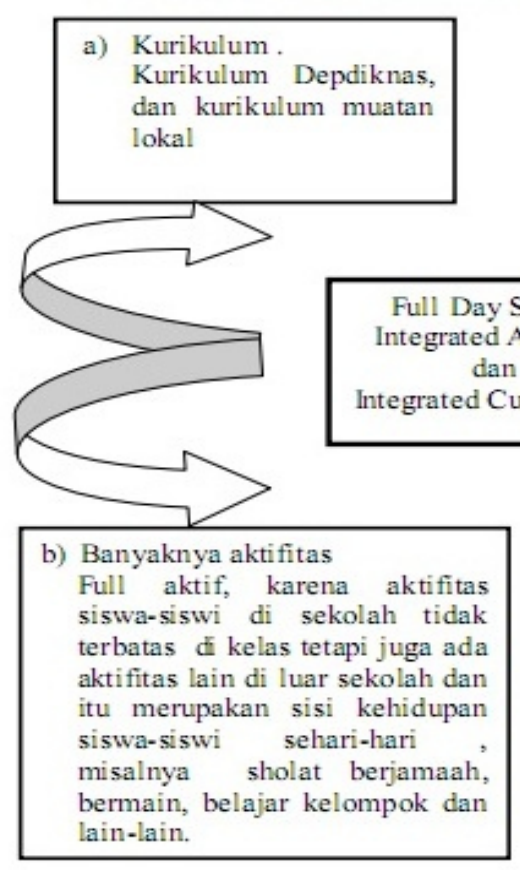

Menurut Fahmi Alaidroes format full day school meliputi beberapa aspek yaitu :

a) Kurikulum yaitu mengintegrasikan atau pemaduan program pendidikan umum dan agama. Dengan memadukan kurikulum umum dan agama dalam suatu jalinan kegiatan belajar mengajar diharapkan peserta didik dapat memahami esensi ilmu dalam perspektif yang utuh.

b) Kegiatan belajar mengajar yaitu dengan mengoptimalisasikan pendekatan belajar berbasis Active Learning siswa mesti 
dirangsang untuk aktif terlibat dalam setiap aktivitas.

c) Peran serta, yakni melibatkan pihak orang tua dan kalangan eksternal (masyarakat) sekolah untuk berperan serta menjadi fasilitator pendidikan para peserta didik.

d) Iklim sekolah, yaitu lingkungan pergaulan, tata hubungan, pola perilaku dan segenap peraturan yang diwujudkan dalam kerangka nilai-nilai islam yang sar'i maupun kaum, nilai islam yang syar'i melandasi segala aspek perilaku dan peraturan yang mencerminkan akhlakul karimah. Sedangkan nilai islam yang kaumi berwujud dalam pola penataan lingkungan yang sesuai dengan hukum-hukum alam.

Pengembangan kurikulum harus dilaksanakan dengan memperhatikan prinsip-prinsip pengembangan kurikulum. Dari pengembangan kurikulum ini diharapkan adanya perbaikan pengelolaan proses KBM yang akan menunjang efektifitas pembelajaran. Pembelajaran yang efektif sesuai dengan kebutuhan dan perkembangan anak akan membantu anak mengoptimalkan bakat, minat, dan potensi positifnya.

\section{KESIMPULAN}

Polarisasi

FDS dalam

pelaksanaannya tidak dapat dihindarkan karena banyak alasan serta adanya konsep FDS untuk sekolah konvensional sesungguhnya memerlukan pengkajian yang lebih mendalam terutama dalam kaitannya dengan kesiapan Sumber Daya. Paling tidak ada dua hal yang sangat menonjol, yaitu:

Pertama, keterbatasan sarana dan prasarana. Sarana dan prasarana merupakan bagian dari pendidikan yang vital untuk menunjang keberhasilan pendidikan. Oleh karena itu perlu adanya pengelolaan sarana dan prasarana yang baik untuk dapat dapat mewujudkan keberhasilan pendidikan. Banyak hambatan yang dihadapi sekolah dalam meningkatkan mutunya karena keterbatasan sarana dan prasarananya.
Keterbatasan sarana dan prasarana dapat menghambat kemajuan sekolah.

Kedua, guru yang tidak profesional. Guru merupakan bagian penting dalam proses belajar mengajar. Keberlangsungan kegiatan belajar mengajar sangat dipengaruhi oleh profesionalitas guru. Akan tetapi pada kenyataannya guru mengahadapi dua yang dapat menurunkan profesionalitas guru. Pertama, berkaitan dengan faktor dari dalam diri guru, meliputi pengetahuan, keterampilan, disiplin, upaya pribadi, dan kerukunan kerja. Kedua berkaitan dengan faktor dari luar yaitu berkaitan denagan pekerjaan, meliputi manajemen dan cara kerja yang baik, penghematan biaya dan ketepatan waktu. Kedua faktor tersebut dapat menjadi hambatan bagi pengembangan sekolah.

\section{DAFTAR PUSTAKA}

Alaydroes, Fahmy. 2010. "Pelaksanaan full day school di SD" http://gudangmakalah.blogspot.com/2010/06 /tesis-pelaksanaan-full-day-school-disd.html,

Arends, Richard. 2008. Learning To Teach.Yogyakarta: Pustaka Pelajar.

Ary, 2011. Administrasi Pendidikan Mikro. Jakarta : Rineka Cipta.

Baharuddin. 2010. Pendidikan dan Psikologi perkembangan. Jogjakarta: Ar-Ruzz Media.

Bogdan, Robert C, and Biklen S.K., (1982). Qualitative Research in Education, Boston, Allyn \& Bacon, inc.

David, Fred R. 2011. Strategic Management Manajemen Strategi Konsep, Edisi 12. Jakarta: Salemba Empat.

Echols, John M. and Shadily, Hassan. 2015. Kamus Inggris-Indonesia, cet.XXVI. Jakarta, PT Gramedia Pustaka.

Engkoswara, dkk. 2010. Administrasi Pendidikan. Bandung: Alfabeta.

Fidler, B. 2012. Strategic Management for School Development. London: Paul Chapman Publishing.

Hamalik, Oemar. 2008. Kurikulum dan Pembelajaran. Bandung: Bumi Aksara.

Hariadi, Bambang. 2013. Strategi Manajemen. Malang: Banyumedia Publishing.

Lincoln, Yvonna S. \& Guba, Egon G. (1985). Naturalistic Inquiry. California, Beverly Hills: Sage Publications. 
Miles, M.B. \& Huberman, A.M. 1992. Analisis Data Kualitatif. Terjemahan oleh Tjetjep Rohendi Rohidi. Jakarta : UI-Press.

Mulyadi. 2011. Akuntansi Manajemen : Konsep, Manfaat dan Rekayasa, Edisi Ketiga. Jakarta: Salemba Empat.

Sardiman. 2010. Interaksi Dan Motivasi Belajar Mengajar. Jakarta: PT Rajagrafindo Persada.

Seli, Muhammad, 2009. Metode pembelajaran pendidikan agama islam dalam full day school di sekolah alam bilingual Madrasah tsanawiyah surya buana Lowokwaru Malang. Skripsi. Fakultas Tarbiyah Universitas Islam Negeri Malang.

Suryosubroto. 2004. Manajemen Pendidikan Di Sekolah. Jakarta, PT. Rieneka Cipta.

Wheelen, Thomas L., Hunger, J. David. 2010. Strategic Management and Business Policy Achieving Sustainability. Twelfth Edition. Pearson. 